\title{
Adaptation of Social Attributes of Place in Creative Placemaking towards Social Sustainability
}

\author{
Nurul Atikah Ramli, Norsidah Ujang \\ Departmentof Landscape Architecture, Faculty of Design and Architecture, \\ Universiti Putra Malaysia, 43400 Serdang, Selangor, Malaysia. \\ atkhnrl.r@gmail.com, norsidah@upm.edu.my
}

\begin{abstract}
Creative placemaking emerges as an evolving field of practice that leverages the power of arts, culture, and creativity to serve the community's interests. Scholars have conveyed the values and benefits of creative placemaking in dealing with social issues and formulating agenda for urban transformation. An extensive review of the literature was conducted to understand the significance of social attributes of place in supporting creative placemaking strategies. A systematic search process yielded 14 articles from 121 documents that have been analyzed systematically. The review found that the social attributes of place generate social opportunities and community-led creative placemaking as catalysts for sustainable urban regeneration.
\end{abstract}

Keywords: Creative placemaking; Social attributes; Social sustainability; Urban regeneration

eISSN 2398-4279 @2020 The Authors. Published for AMER ABRA cE-Bs by e-International Publishing House, Ltd., UK. This is an open access article under the CC BY-NC-ND license (http://creativecommons.org/licenses/bync-nd/4.0/). Peer-review under responsibility of AMER (Association of Malaysian Environment-Behaviour Researchers), ABRA (Association of Behavioural Researchers on Asians) and $c E-B s$ (Centre for EnvironmentBehaviour Studies), Faculty of Architecture, Planning \& Surveying, Universiti Teknologi MARA, Malaysia.

DOI: https://doi.org/10.21834/ajqol.v5i18.202 


\subsection{Introduction}

There is a remarkable transition where the world's population is moving from rural to mainly urban living, and it was forecast that by the year $2050,70 \%$ of the world population will be living in urban areas (Rashid, 2018). This scenario is evident in Malaysia, whereby an approximately 18 million population today are living in town and cities (Sulaiman \& Ibrahim, 2019). Social issues that occurred from the population growth and ongoing inward migration have resulted in social issues reflected in the erosion of community identity, social cohesion, and cultural value (KARACOR, 2014). With rapid urbanization and constant increase of population, the availability and quality of urban spaces have become a crucial component in urban areas (Ibrahim, Omar, \& Nik Mohamad, 2019), which plays a significant role in the community life and social development.

With that being mentioned, creative placemaking emerges as an evolving field of practice that intentionally leverages the power of the arts, culture, and creativity to serve a community's interest while driving a broader agenda for change, growth, and transformation of cities and places. The concept of creative placemaking supports the Sustainable Development Goals (SDG 11), promoting an environment to be inclusive, safe, resilient, and sustainable (UNESCO, 2015). SDG 11 has become an essential indicator at every level of development planning. It recognizes the importance of urban development, which enhances social and economic productivity providing a better quality of life (Rashid, 2018). In this regard, creative placemaking also has a close relevance with one of the strategies outlined in the Kuala Lumpur Declaration on Cities 2030, to foster a culture of creativity and innovation within the way cities operate.

Table 1. Studies on creative placemaking

\begin{tabular}{|c|c|c|c|}
\hline $\begin{array}{l}\text { Process } \\
\text { of change }\end{array}$ & $\begin{array}{l}\text { Drivers } \\
\text { of change }\end{array}$ & $\begin{array}{l}\text { Author(s), } \\
\text { Year }\end{array}$ & Scope of study \\
\hline $\begin{array}{l}\text { Top-Down, } \\
\text { Master } \\
\text { Planned }\end{array}$ & $\begin{array}{l}\text { Government, } \\
\text { Developers, } \\
\text { Socio- } \\
\text { Political } \\
\text { Structure }\end{array}$ & $\begin{array}{l}\text { (Salzman } \\
\text { \& Yerace, } \\
\text { 2018) }\end{array}$ & $\begin{array}{l}\text { Creative placemaking as socio-political events holding } \\
\text { closer connections with other participants and the } \\
\text { community. } \\
\text { - Explores a new form of associational } \\
\text { behaviordescribing creative placemaking that seeks } \\
\text { to activate a public-facing space through the } \\
\text { deliberate actions of people in a built environment } \\
\text { and driven by the work of urban and community } \\
\text { planners. } \\
\text { Focused on to what extent those individuals } \\
\text { understand and define placemaking and the } \\
\text { outcomes as well as implications of that } \\
\text { behavior(creative placemaking) }\end{array}$ \\
\hline
\end{tabular}


(Arroyo, Creative placemaking as grounding practices expanding 2017) the application of innovative practices to participatory policymaking, where a comprehensive set of stakeholders can advance a more transformative model of equitable development.

- $\quad$ Explained that policy change offers the most direct route to advancing equity in which can be achieved in inclusive practices like creative placemaking

- Examines how the rules of civic problem-solving are evolving to prioritize citizenship and leverage local knowledge, one expression of culture, by drawing on longstanding discourse in fields that range from several stakeholders where inclusive practice like creative placemaking can be done.

(Nicodem Creative placemaking has been introduced as a significant us, 2013) new U.S. cultural policy and funding trend; wherein crosssector partners strategically shape the social and physical characteristics of a place (ranging from neighborhoodsto region) around arts and cultural assets.

$\begin{array}{lll}\text { Co- } & \text { Collaborative } & \text { (Bennett, } \\ \text { Management, } & \text {,NGOs } & \text { 2014) } \\ \text { Co-Creation, } & & \\ \text { Public } & & \\ \text { Participation } & & \end{array}$

(Redaelli, 2018)

(Zitcer, 2018)
Identification of the benefits from the evaluation of the selected projects provided by ArtPlace America.

- Explain the framework that has been provided by ArtPlace America, and he then chooses 16 ArtPlace grantee projects to evaluate creative placemaking initiatives.

Creative placemaking as a bottom-up cultural policy developed by the NEA, where it brings community development and the arts together, demonstrating a convergence between government action and theories of art, such as public art, community-based art, and social practice.

- Focusing on two different literature reviews contribute to the urban cultural policy literature articulating and exemplifying how a place-based cultural policy works.

- Illustrating the impact of federal government initiatives at the local level and bringing to the forefront the artistic discourse intertwined with it.

- Examine the connections of urban cultural policy with the art world and its theories created an understanding of how the two sectors already cooperate, highlighting their common grounds.

Analyzing the emergence and ongoing contestation of this term, contrasting the way creative placemaking is understood and enacted by actors in Philadelphia with definitions employed by national funders

- Argues that practitioners and community voices deserve amplification in the unfinished work of 
creative placemaking as urban practice.

- $\quad$ Explained it fits such a structure, in which experts in institutions produce knowledge that places people into categorizations. All the protagonists in this structure have a responsibility to engage in an ongoing, collective process of definition.

\begin{tabular}{|c|c|c|c|}
\hline \multirow[t]{6}{*}{$\begin{array}{l}\text { Bottom-Up } \\
\text { Approach }\end{array}$} & \multirow[t]{6}{*}{$\begin{array}{l}\text { Individuals, } \\
\text { Local } \\
\text { Groups, } \\
\text { Human } \\
\text { Agency }\end{array}$} & $\begin{array}{l}\text { (Morley \& } \\
\text { Winkler, } \\
\text { 2014) }\end{array}$ & $\begin{array}{l}\text { Study on the livability indicator to reflect four key } \\
\text { dimensions, which are resident attachment to the } \\
\text { community, quality of life, arts and cultural activity, and } \\
\text { economic conditions in evaluating the impact of creative } \\
\text { placemaking. }\end{array}$ \\
\hline & & $\begin{array}{l}\text { (Markusen } \\
\text { \& Gadwa } \\
\text { Nicodemu } \\
\text { s, 2014) }\end{array}$ & $\begin{array}{l}\text { Reflects on the origins of creative placemaking } \\
\text { emphasizing three features to evaluate how well the } \\
\text { creative placemaking evolved in practice over the last four } \\
\text { years. } \\
\text { Explaining the need of three feature (strategic action } \\
\text { by cross-sector partners, a place-based orientation, } \\
\text { and a core of arts and cultural activities) for creative } \\
\text { placemaking to do well and gives a good impact } \\
\text { such as strive for more than job creation, reuse of } \\
\text { abandoned buildings, commercial retail sales- } \\
\text { traditional economic development results and } \\
\text { emphasized more fully the importance of equity. }\end{array}$ \\
\hline & & $\begin{array}{l}\text { (Pak, } \\
2018)\end{array}$ & $\begin{array}{l}\text { Creative placemaking has been identified as having } \\
\text { several opportunities for Singapore to gradually develop } \\
\text { into a more inclusive and genuinely participatory practice } \\
\text { localizing social and spatial regeneration. }\end{array}$ \\
\hline & & $\begin{array}{l}\text { (Forsyth, } \\
2014 \text { ) }\end{array}$ & $\begin{array}{l}\text { Identify that the emerging creative placemaking field has a } \\
\text { different but complementary set of assets leads the ability } \\
\text { to address the intangibles that make a strong and vibrant } \\
\text { community, mobilize social capital, bring performance and } \\
\text { participatory activities to public spaces and challenge } \\
\text { preconceptions about what a city is supposed to look like } \\
\text { and how it works. }\end{array}$ \\
\hline & & $\begin{array}{l}\text { (Rembeza } \\
\text {, 2016) }\end{array}$ & $\begin{array}{l}\text { Examine the role of creative placemaking in shaping an } \\
\text { urban environment where the findings show the Mural Arts } \\
\text { in Philadelphia has significantly changed the appearance } \\
\text { of the city and what is more crucial demonstrated how } \\
\text { participatory public art could empower individuals }\end{array}$ \\
\hline & & $\begin{array}{l}\text { (Newton, } \\
2017 \text { ) }\end{array}$ & $\begin{array}{l}\text { Creative placemaking activities are presented as } \\
\text { pedagogical tools for connecting arts entrepreneurship } \\
\text { and community development goals where it was a desire } \\
\text { to extend beyond the dominant paradigm of both arts } \\
\text { entrepreneurship and community development concerning }\end{array}$ \\
\hline
\end{tabular}


the economic development of the individual and collective.

(Source: Adapted from Salzman \& Yerace, 2018; Arroyo, 2017;Vazquez, 2014; Bennett, 2014; Radaelli, 2018; Morley \& Winkler, 2014;Zitcer, 2018; Markusen \& Gadwa Nicodemus, 2014, Pak, 2018; Nicodemus, 2013; Rembeza,2016; Forsyth, 2014; Newton, 2017)

Placemaking is the process of transforming spaces into places by integrating the social dimension of planning and linking meaning and function to the spaces. While there is no agreed definition of placemaking, it is typically understood as a process that is part of urban design that makes places livable and purposeful (Flemming, 2007; PPS, 2008). Placemaking activates our built and lived environment enhancing the quality of life (Christina Lanzl, Tullis, \& Schultz, 2017). Nasution\&Zahrah (2012) evaluate the perception of society towards physical quality aspects of public open space, which is required in designing public open space to reinforce the good quality of life. Though an adequate amount of research on creative placemaking has been carried out, as shown in Table 1 above, most of the precedent studies explored the process and drivers of change in creative placemaking. As to date, only a few studies have attempted to establish indicators and assessing the performance outcomes of successful creative placemaking (Markusen \& Gadwa, 2010; Esarey, 2014), particularly in terms of social space and social dimension. This study is, therefore, set to understand the relationship between creative placemaking and urban place in the urban design context. It aims to address this gap by illustrating a more comprehensive understanding of how creative placemaking can be applied in urban development. This paper explores two major concepts, which are creative placemaking and urban design attributes of a place. It defines the relationship of social opportunity, which is one of the components in creative placemaking and social attributes of places in urban design. An extensive literature review was gauged by the research question - what are the most significant urban design attributes of places that support creative placemaking?

\subsection{Methodology}

A systematic review was done to seek relevant articles from search engines, including Science Direct, Scopus, and Web of Science. 


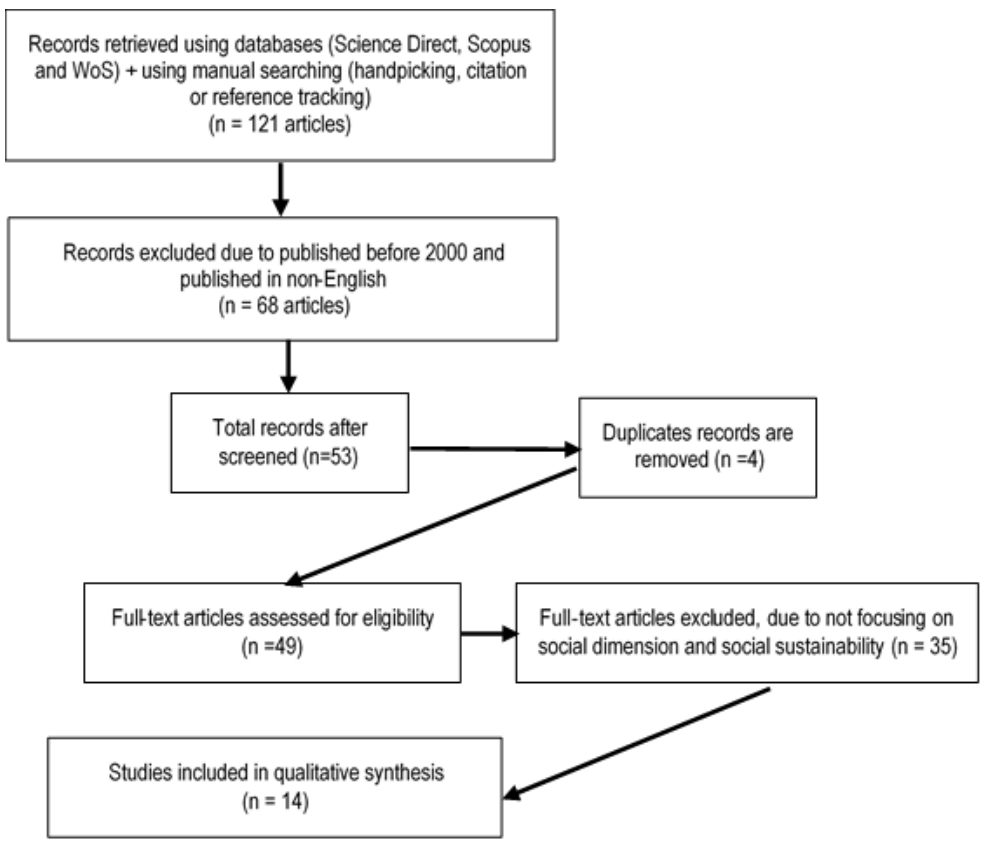

Fig. 1: Workflow diagram of selection of relevant articles (Source: Authors, 2020)

\subsection{Identification of key terms}

The systematic review process in selecting several relevant materials for the present study consolidated with the identification of words, followed by the process of searching for related and similar terms based in a thesaurus and past researches. All the documents have been retrieved by using Boolean operators. As a result, this process provides a total of 121 documents.

Table 2. The search string

\begin{tabular}{cl}
\hline \multicolumn{1}{c}{ Search string } \\
\hline i. & urban design attributes = "urban design qualities" OR "urban design \\
ii. & component" OR "urban design elements" \\
iii. & creative placemaking = "creative place-making" OR "creative place making." \\
\hline
\end{tabular}

\subsection{Screening}

Inclusion and exclusion criteria were developed as a second stage to determine relevant articles before the review (Moher et al., 2009). The purpose of this stage was to remove duplicate articles, and four criteria were developed; timeline, language, subject terms, and 
level of planning. A total of 72 articles were discarded during the screening process. Of the usable 49 articles, only $12 \%$ were found that is applicable to the scope of the study, which to cater social dimension in urban place and creative placemaking. The rest were related to creative placemaking and attributes of urban place in general. Exclusion criteria included articles that focused on urban design attributes other than social and activity and creative placemaking that is not focusing on the social dimension.

Table 3. The inclusion and exclusion criteria

\begin{tabular}{lll}
\hline Criterion & Inclusion & Exclusion \\
\hline Timeline & $2000-2019$ & $<2000$ \\
Language & English & $\begin{array}{l}\text { Non-English } \\
\text { Subject focus }\end{array}$ \\
Social/activity attributes and & $\begin{array}{l}\text { Physical form and meaning attributes } \\
\text { and non-social dimension }\end{array}$ \\
Level of planning & Community/social development & $\begin{array}{l}\text { Other than community } \\
\text { (district/government policy making) }\end{array}$ \\
& &
\end{tabular}

This paper seeks to establish the relationship between creative placemaking and social attributes of places in urban design scope of knowledge based on the chosen publications. The relevant keywords and terms which are 'attributes of places,' 'arts,' 'culture and creativity,' 'creative placemaking,' 'urban design,' and 'social sustainability' were reviewed to develop a theoretical framework exploring each concept and importance in urban development. A total of 14 articles were considered as the central references in developing the four proposed adaptation strategies of creative placemaking for social sustainability (see Table 4), whereas the remaining articles provided supporting references. The following section depicts the concept of creative placemaking, its element, benefits, and challenges in applying the concept in reality.

\subsection{An Overview of Creative Placemaking Concept}

Creative placemaking is defined as vitalizing public and private spaces, regenerates structures and streetscapes, boost local business viability and public security, and brings various people along to celebrate, inspire, and be inspired (Markusen \& Gadwa, 2010). It deals with the utilization of arts, culture, and creativity practices to make a place more attention-grabbing (Cohen et al., 2018). Creative placemaking has close pertinence to the innovative solution that has been laid out in the Kuala Lumpur Declaration on Cities 2030, cultivating a culture of creativity and innovation within the way of cities' work. Innovation not only advances new thoughts of creativity but also creates a range of new employments. At a time of rising social inequality, innovation has become an avenue to generate economic opportunities for social advancement. The term "creative" in "placemaking" relates to the 
aspect of a place where individuals are engaging and making places, celebrating the history and distinctive culture, adding layers of meanings, and creating a shared vision for the community (Redaelli, 2018). For creative placemaking to happen, the physical form, social opportunity, and quality places are needed (Wyckoff, 2014). The elements of interest of creative placemaking: place-based orientation, art-based orientation, community, and cultural development constitute the creative placemaking components (see Fig.2).

\subsection{Elements of Creative Placemaking}

Creative placemaking is an empowering process that contributes positively to social development. Place-based orientation focused on the connection resulting in how people feel and respond to the elements in their places whereas asset-based orientation focus on the development of asset using arts and culture as tools for the creation of cultural spaces, activating the creative potential in communities, bringing performance and participatory activities to public spaces (Forsyth, 2014; Vazquez, 2014; Zitcer, 2018). Cultural development focuses on enhancing the places where arts and creativity can flourish, whereas community development concerns improving the quality of life by providing places that fulfill social and human needs (Vazquez, 2014).

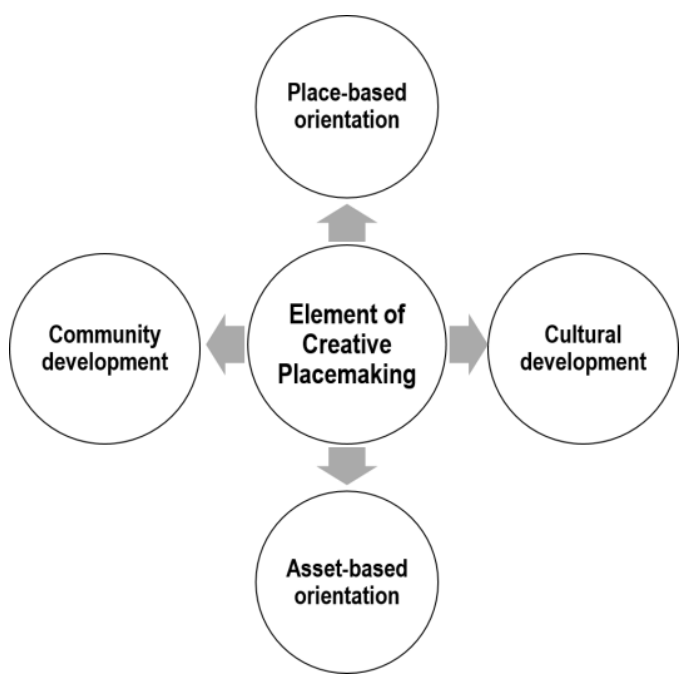

Fig. 2: Creative placemaking and its elements

(Source: Adapted from Wyckoff, 2014) 


\subsection{Value and Benefits of Creative Placemaking}

The benefits and values of creative placemaking have been linked to the increase in economic development, strengthen community connection and sustainable and higher quality of life (Markusen \& Gadwa, 2010; Forsyth, 2014; Vazquez, 2014) (see Fig.3). Hence, further discussion in this paper is primarily dwelling upon social measurement. The use of arts and culture provide significant returns on investment for the goals of both community and economic development (Vazquez, 2014). Creative placemaking is able to address the intangibles qualities that make thriving and vibrant places, bringing diverse people together and increase civic engagement. The attachment of the community to the place embraces the attraction of visitors, businesses, and investments, thus mobilize social capital (Markusen \& Gadwa, 2010; Forsyth, 2014). Creative placemaking gives an impact on economic development where it provides new job creation (Markusen\& Gadwa, 2010). Creative placemaking enhances the creative economy, provides more entryways to prosperity for individuals and communities, as a result, achieving a higher quality of life.

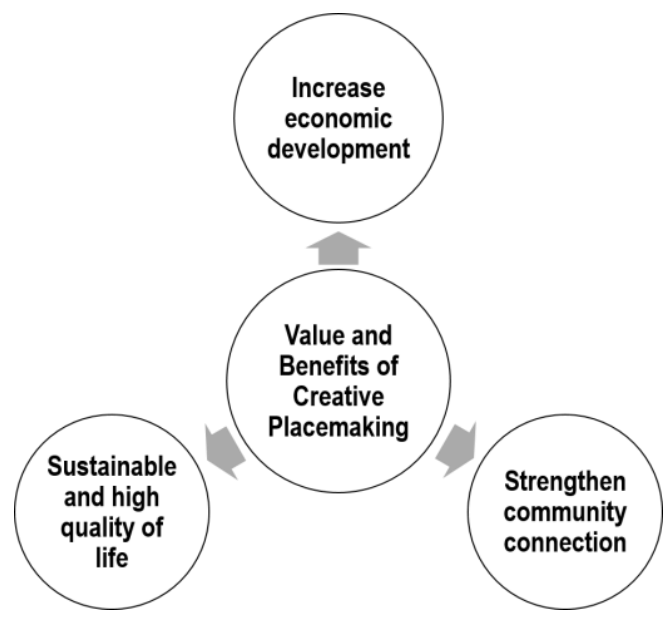

Fig. 3: Value and benefits of creative placemaking

(Source: Adapted from Markusen \& Gadwa, 2010; Forsyth, 2014; Vazquez, 2014) 


\subsection{Issues and Challenges of Creative Placemaking}

Zitcer (2018) stated that the challenge to materialize creative placemaking is the vulnerability and confusion over the understanding of the concept and what activities ought to be classified beneath that rubric and how to measure their effectiveness. The meaning of creative placemaking might differ from each person. This concern broad pressures around the part of creative placemaking in supporting gentrification. Gentrification causes spatial and social changes (Sholihah\& Heath, 2016), inequality among people, displacement, and dis-belonging (Frenette, 2017). In the context of urban design, Markusen \& Gadwa (2010) argues that there is sorely lacking in knowledge on workable strategies at urban and regional scale failing to specify goals, reliance on fuzzy theories, underdeveloped of public participation and unwillingness to require and evaluate the performance of creative placemaking. In this way, how can creative placemaking redefine the function and meaning of places, and how does this community-oriented approach can provide a way to lessen social issues towards accomplishing social sustainability and sustainable urban regeneration?

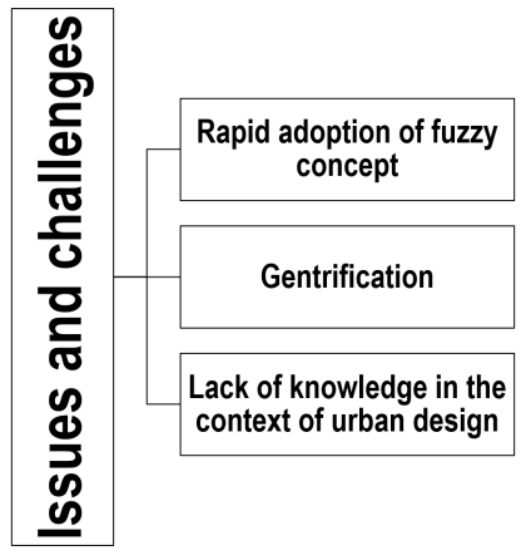

Fig. 4: Issues and challenges pertaining to creative placemaking

(Source: Adapted from Zitcer, 2018; Frenette, 201; Morley \& Winkler, 2014; Markusen \& Gadwa, 2010)

\subsection{Social Opportunityand Creative Placemaking}

A thriving creative placemaking is not determined by how many new arts centers, shows, or social-cultural areas are planned. Instead, its success is assessed through the way innovative intervention contributes toward social outcomes (Bennett, 2014). Due to the significance of creative placemaking in supporting the social life of communities, this study 
examines social opportunities as the enabling factor of successful placemaking. People who are affected by gentrification should be given the opportunity to deliberate ways to mitigate the issues (Cohen, Wiek, Kay, \& Harlow, 2015). The process provides a chance for the community to make a representation (Ismail \& Said, 2015) in creating creative placemaking. The need is to facilitate the people with spaces for social and cultural activities, create opportunities for people to get involved and feel included, allowing for the place and the community to evolve (Ujang, 2016). In the context of urban design and placemaking, it is therefore vital to examine the social attributes of place and their roles in creative placemaking in light of the people's needs for social life.

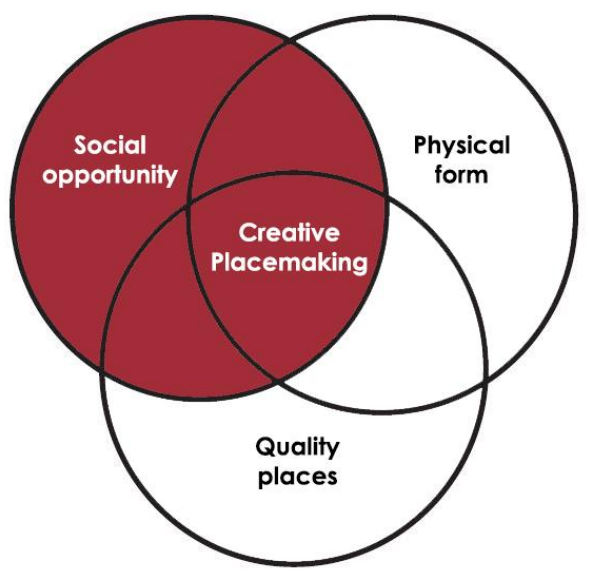

Fig. 5: Creative placemaking and its main components (Source: Wyckoff, 2014)

Within the sense of creative placemaking, people should be encouraged to socialize in a vital urban space giving them a huge opportunity to enjoy and appreciate their environment. Diversity of place resulted from an intensifying and mixing between people and activities, makes places more diverse, exciting, and active space advancing a spontaneous chance to interact with others (Government Architect NSW, 2017). Inclusiveness of place propels social inclusion, ensuring that individuals have both the right and the opportunity to take part in and enjoy all aspects of community life (Lieshout\&Aarts, 2008). It also improves community sentiments, and the sense of ownership towards the city, and the sense of belonging to a place (Ujang, 2016). The value of a place is where people were exposed to the unique culture and community vibrancy in that particular place, allowing them to learn about each other's cultural identity and character, which could not be found elsewhere (Forsyth, 2014). 


\subsection{Social Opportunity Signifies Social Sustainability}

Creative placemaking frame a new associational behavior which it seeks to enact places through the action and activities of people in a built environment (Salzman \& Yerace, 2018). Social sustainability, on the other hand, aims to offer opportunities, making a choice subsequently lead to a high quality of life (Jaffar, Harun, \& Mansor, 2019). It defines people's quality of life and depicts the degree to which a neighborhood supports individual and collective well-being (Ujang, 2016). Creative placemaking in this context can be regarded as an essential strategy in making good places. In this manner, the vital part of creative placemaking involves the people and the spaces that infuse social functions and meanings.

\subsection{Interrelation between Creative Placemaking and Urban Place}

From a review of creative placemaking's literature, most of the precedent studies had analyzedits significant considerations (Salzman \& Yerace, 2018), characterized and standardizes the measurement of creative placemaking (Morley \& Winkler, 2014), and recognized the benefits of creative placemaking (Bennett, 2014). Hence, this paper presents the main findings of the reviews by connecting the social components of place with urban design social attributes. The interrelationship between the components denotes the significance of urban design attributes in shaping a creative placemaking.
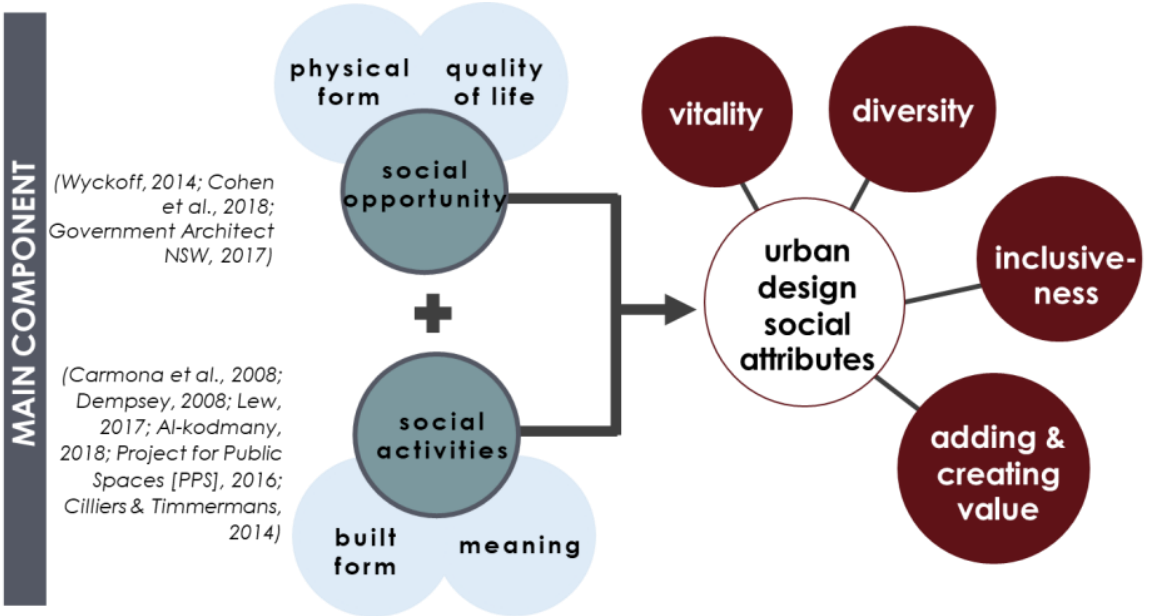

Fig. 6: Linking Components of Creative Placemaking and Urban Place (Source: Authors, 2020) 
Esarey (2014) stated that many studies had been conducted to grasp the economic, social, and environmental impacts of creative placemaking in a bigger context, while a few studies have exclusively attempted to form an indicator evaluating the performance of creative placemaking. This study is imperative because it is explicitly centering on understanding the integration between the component of creative placemaking, which is the social opportunity and social attributes of a place. Table 4 outlined the social attributes of a place that can be adapted in designing a place for creative placemaking:

Table 4. Adaptation of Social Attributes of Place in Creative Placemaking

\begin{tabular}{|c|c|c|}
\hline Derived and adapted from: & $\begin{array}{l}\text { Social Attributes of } \\
\text { Place }\end{array}$ & $\begin{array}{l}\text { Adaptation strategies suggested in the creation } \\
\text { of creative placemaking }\end{array}$ \\
\hline $\begin{array}{l}\text { (Carmona, 2009; Carmona, } \\
\text { Magalhales, \& Hammond, 2008; } \\
\text { Dempsey, 2008; Del Aguila, } \\
\text { Ghavampour, \& Vale, 2019). }\end{array}$ & Vitality of place & $\begin{array}{l}\text { A vital place that consists of multiple activities, } \\
\text { stimulating, providing more participatory activities } \\
\text { and has the intensity of crowds could offer social } \\
\text { opportunity to socialize among each other }\end{array}$ \\
\hline $\begin{array}{l}\text { (Cilliers\& Timmermans, 2014; } \\
\text { Placesore, 2015; Richards, 2015; } \\
\text { Project for Public Spaces, 2016; } \\
\text { Government Architect NSW, 2017) }\end{array}$ & Diversity of place & $\begin{array}{l}\text { Diversity of place provide continuous activities, } \\
\text { variety of products and services, and have a } \\
\text { mixture of people allowing them to interact with } \\
\text { each other, stumble onto the fun and mingle with } \\
\text { other people. }\end{array}$ \\
\hline $\begin{array}{l}\text { (Carmona et al., 2008; Dempsey, } \\
\text { 2008; Project for Public Spaces, } \\
\text { 2016). }\end{array}$ & Inclusiveness of place & $\begin{array}{l}\text { Inclusiveness of place should be designed to be } \\
\text { conducive, welcoming to all and comfortable for a } \\
\text { walkthrough, sit, play and talk offering an } \\
\text { opportunity to people with various types of } \\
\text { disabilities and ages to be in that place }\end{array}$ \\
\hline $\begin{array}{l}\text { (Markusen \& Gadwa, 2010; Center } \\
\text { for Creative Placemaking, 2014; } \\
\text { Ujang, 2016; Alzahrani, Borsi, } \\
\text { \&Jarman, 2017; Government } \\
\text { Architect NSW, 2017). }\end{array}$ & Value of place & $\begin{array}{l}\text { Place with value should have its uniqueness, } \\
\text { providing more performance and exhibition } \\
\text { strongly related to culture, allow sharing } \\
\text { experiences and knowledge with others, support } \\
\text { understanding, unity and promote community } \\
\text { building which gives people opportunity to gain } \\
\text { benefits for their quality of life }\end{array}$ \\
\hline
\end{tabular}

(Source: Authors, 2020)

The findings are pertinent in dealing with gentrification that causes relocation, displacement, and social changes. Creative placemaking integrates social attributes of place with social components of placemaking (see Table 4). The attributes of a place discussed in the next section were identified based on the recurrence mention in urban design literature and considered as qualities of good urban design within the setting of creative placemaking. 


\subsection{Discussion}

The social opportunity is a condition where people have a chance to take part in the creation of creative placemaking that is entwined with the social attributes of a place. By referring to urban design as a tool towards sustainable development, it is believed that adaptation of a multi-dimensional placemaking based on knowledge and innovation of urban spaces offers a different range of social, cultural, and democratic needs that can be achieved (Pancholi, Guaralda, \&Yigitcanlar, 2017). A place with socially responsive attributes could generate social opportunities that can bring people closer, develop a civic identity, and promoting economic advancement.

Vitality, diversity, inclusiveness, and value are prudent attributes in creating spaces in creative placemaking. The vitality of a place should promote multiple activities, creating a sense of enjoyment, and stimulating with the people's presence. Diversity of place suggests making spaces multifunctional, grasping a richness in use and activity, and offering maximum utilization of spaces that attract people to participate (Government Architect NSW, 2017). Inclusiveness of place is vital in creating a sense of welcoming to all and embraces the community and individuals who use urban places (Dempsey, 2008). Finally, the authenticity of successful creative placemaking is when a place is generating a persistent value in terms of adding personal and social values and raising the quality of life of communities, as well as gaining a return on investment for industry (Government Architect NSW, 2017). As briefly discussed earlier, these social attributes offer social sustainability in which, in the context of creative placemaking, generates social opportunity. These noteworthy findings support creative placemaking as an enabler for sustainable urban regeneration.

\subsection{Conclusion and Recommendation}

The issue of social seclusion and displacement can be approached by adopting creative placemaking strategies. The review on the concept of creative placemaking highlights the importance of social dimension and its corresponding attributes. It recognizes the adaptation of vitality, diversity, inclusiveness and meaningful value of place as strategies in designing a place; however, without the social and cultural engagement of the people in place offering positive values and benefits, the creative placemaking will not achieve its goal as a catalyst in fostering a culture of creativity and innovation.

Finally, this paper elucidates a more comprehensive understanding of how creative placemaking conjoint with the urban design social attributes that would aid planners and other decision-makers in crafting strategies in urban regeneration towards social sustainability. Fig. 7. shows how major key concepts in this study are interrelated. 


\section{ISSUE}

urbanization causing the social changes, people displacement, erosion of community identity and cultural values

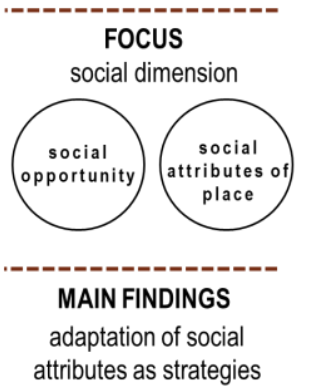

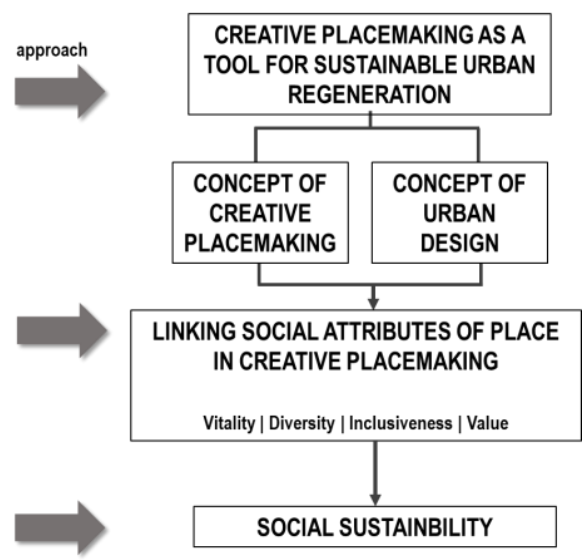

Fig. 7: Theoretical Framework of Creative Placemaking as an Enabler in Sustainable Urban Regeneration

(Source: Authors, 2020)

\section{Acknowledgement}

The authors acknowledge the Universiti Putra Malaysia for partly funding and facilitating the research under the Putra Grant Scheme (UPM/GP/2017/9577200).

\section{References}

Alzahrani, A., Borsi, K., \& Jarman, D. (2017). Place-making and its implications for social value: A comparison study of two urban squares in London. International Journal of Sustainable Development and Planning, 12(4), 752762. https://doi.org/10.2495/SDP-V12-N4-752-762

Arroyo, K. K. (2017). Creative Policymaking: Taking the Lessons of Creative Placemaking To Scale. Artivate: $A$ Journal of Entrepreneurship in the Arts, 6(2), 58-72. Retrieved from http://search.ebscohost.com/login.aspx?direct=true\&db=bth\&AN=125761105\&site=eds-live\&scope=site

Bennett, J. (2014). Creative Placemaking in Community Planning and Development: An Introduction to ArtPlace America. Community Development Investment Review, 10(2), 77-84. Retrieved from http://www.frbsf.org/community-development/files/creative-placemaking-in-community-planning-and-developmentan-introduction-to-artplace-america.pdf

Carmona, M. (2009). Sustainable urban design: principles to practice. International Journal of Sustainable Development, 12(1), 48. https://doi.org/10.1504/ijsd.2009.027528

Carmona, M., Magalhales, C. de, \& Hammond, L. (2008). Public Space: The Management Dimension. London: Routledge, 2008. https://doi.org/10.4324/9780203927229 
Center for Creative Placemaking. (2014). What is Creative Placemaking? Center for Creative Placemaking Website. Retrieved from http://centerforcreativeplacemaking.net/what-is-creative-placemaking/action/

Lanzl, C., Tullis, R. and Schultz, A., 2017. Placemaking Manifestation. [Online] Urbancultureinstitute.org. Available at <https://www.urbancultureinstitute.org/uploads/1/1/4/6/11465358/placemaking_manifesto.pdf> [Accessed 17 April 2019].

Cilliers, E. J., \& Timmermans, W. (2014). The importance of creative participatory planning in the public placemaking process. Environment and Planning B: Planning and Design, 41(3), 413-429. https://doi.org/10.1068/b39098

Cohen, M., Gajendran, T., Lloyd, J., Maund, K., Smith, C., Bhim, S., \& Vaughan, J. (2018). Communities of Practice Collaborative Project Stage 1: Literature Review 2018 Valuing Creative Place Making: Development a Toolkit for Public and Private Stakeholders. Retrieved from tps://www.landcom.com.au/assets/Uploads/researchlearning-creative-place-making.pdf

Cohen, M., Wiek, A., Kay, B., \& Harlow, J. (2015). Aligning public participation to stakeholders' sustainability literacy-A case study on sustainable urban development in Phoenix, Arizona. Sustainability (Switzerland), 7(7), 8710-8728. https://doi.org/10.3390/su7078709

Del Aguila, M., Ghavampour, E., \& Vale, B. (2019). Theory of Place in Public Space. Urban Planning, 4(2), 249. https://doi.org/10.17645/up.v4i2.1978

Dempsey, N. (2008). Quality of the built environment in urban neighbourhoods. Planning Practice and Research, 23(2), 249-264. https://doi.org/10.1080/02697450802327198

Esarey, K. (2014). Validating livability and vibrancy: an examination of the use of indicators in creative $\begin{array}{llll}\text { placemaking. } & 88 . & \text { Retrieved }\end{array}$ https://etd.ohiolink.edu/pg_10?0::NO:10:P10_ACCESSION_NUM:ucin1397235448

Fleming, R., 2007. The Art of Placemaking: Interpreting Community through Public Art and Urban Design. London: Merrell, pp. (374-378).

Forsyth, M. (2014). Community development investment review: Creative placemaking. Federal Reserve Bank of San Francisco, 10(2), 87-98.

Frenette, A. (2017). The Rise of Creative Placemaking: Cross-Sector Collaboration as Cultural Policy in the United States. Journal of Arts Management Law and Society, 47(5), 333-345. https://doi.org/10.1080/10632921.2017.1391727

Government Architect NSW. (2017). Strategy for Action Delivering Better Placed - an integrated design policy for New South Wales - Better Placed.

Hecht, Ben (2009). Opportunity at the Intersection of Community Development and Creative Placemaking. Community Development Investment Review, 2(October), 5-9.

Ibrahim, F. I., Omar, D., \& Nik Mohamad, N. H. (2019). Human Interaction In Urban Open Spaces. EnvironmentBehaviour Proceedings Journal, 4(10), 188. https://doi.org/10.21834/e-bpj.v4i10.1590

Ismail, W. A. W., \& Said, I. (2015). Integrating the Community in Urban Design and Planning of Public Spaces: A Review in Malaysian Cities. Procedia - Social and Behavioral Sciences, 168(January), 357-364. https://doi.org/10.1016/j.sbspro.2014.10.241

Jaffar, N., Harun, N. Z., \& Mansor, M. (2019). The Key Determinant Factors for Social Sustainability in Traditional 
Settlement. Environment-Behaviour Proceedings Journal.

KARACOR, E. K. (2014). PlaceMaking Approachment to Accomplish Social Sustainability. European Journal of Sustainable Development, 3(4), 253-262. https://doi.org/10.14207/ejsd.2014.v3n4p253

Lieshout, M. V., \& Aarts, N. (2008). Youth and Immigrants' Perspective on Public Spaces. Journal of space and culture, 11(4), 497-513.

Markusen, A., \& Gadwa, A. (2010). Arts and culture in urban or regional planning: A review and research agenda. Journal of Planning Education and Research, 29(3), 379-391. https://doi.org/10.1177/0739456X09354380

Markusen, A., \& Gadwa Nicodemus, A. G. (2014). Creative Placemaking: How to Do it Well. Community Development Investment Review, 2(October), 35-42. https://doi.org/10.3109/17435390.2011.579634

Morley, E., \& Winkler, M. K. (2014). Assessing a Set of Indicators for Creative Placemaking: Reflections From the Field. Community Development Investment Review, 36(December), 49-55. Retrieved from http://www.frbsf.org/community-development/files/assessing-a-set-of-indicators-for-creative-placemakingreflections-from-the-field.pdf

Mrđenović, T. (2011). INTEGRATIVE URBAN DESIGN IN REGENERATION - PRINCIPLES FOR ACHIEVING SUSTAINABLE PLACES. Journal of Applied Engineering Science, 9(2), 305-316.

Nasution, A. D., \& Zahrah, W. (2012). Public Open Space Privatization and Quality of Life, Case Study Merdeka Square Medan. Procedia - Social and Behavioral Sciences, 36(September), 466-475. https://doi.org/10.1016/j.sbspro.2012.03.051

Newton, T. (2017). INSPIRING SOULFUL COMMUNITIES THROUGH MUSIC: CONNECTING ARTS ENTREPRENEURSHIP EDUCATION AND COMMUNITY DEVELOPMENT VIA CREATIVE PLACEMAKING. Artivate: A Journal of Entrepreneurship in the Arts, 6(1), 33-45. Retrieved from https://artivate.hida.asu.edu/index.php/artivate/article/view/139/61

Nicodemus, Anne Gadwa (2013). Fuzzy vibrancy: Creative placemaking as ascendant US cultural policy. Cultural Trends, 22(3-4), p. 213-222. Doi: http://www.tandfonline.com/10.1080/09548963.2013.817653.

Pak, Yulia (2018). Creative Placemaking as a Policy and a Practice of Urban Regeneration in Singapore: Negotiating Power and Forging Partnerships in Civic Society. Asia Research Institute Working Paper Series No. 268, p.1-21.

Pancholi, S., Guaralda, M., \& Yigitcanlar, T. (2017). Context, contribution and characteristics of public spaces for place making in contemporary knowledge and innovation spaces. Observations from Brisbane, Australia. The Journal of Public Space, 2(4), 91. https://doi.org/10.5204/jps.v2i4.143

Project for Public Spaces [PPS]. (2018). What is Placemaking? [Online] Available at: $<$ https://www.pps.org/article/what-is-placemaking [Accessed 5 May 2019].

Project for Public Spaces [PPS]. (2016). Placemaking: what If we built our cities around places ?, 1-24. Retrieved from http://www.pps.org/wp-content/uploads/2016/10/Oct-2016-placemaking-booklet.pdf

Rashid, A. A. (2018). Urbanice malaysia. The Fourth Industrial Revolution Impact To the Future of Sustainable Urban Development in Malaysia, 1-25.

Redaelli, E. (2018). Creative placemaking and theories of art: Analyzing a place-based NEA policy in Portland, OR. Cities, 72(October 2017), 403-410. https://doi.org/10.1016/j.cities.2017.10.001 
Rembeza, Magdalena (2016). Shapping Places through Art. The Role of Creative Placemaking in Philadelphia. Sqem 2016, Bk 4: Arts, Performing Arts, Architecture and Design Conference Proceedings, Vol ii (April), p. 601607.

Richards, G. (2015). Placemaking and events in the network society. Cities in Transition Conference, March 12th 2015, 1-10. https://doi.org/10.3727/152599515X14465748512849

Salzman, R., \& Yerace, M. (2018). Toward understanding creative placemaking in a socio-political context. City, Culture and Society, 13(October 2017), 57-63. https://doi.org/10.1016/j.ccs.2017.10.004

Sholihah, A. B. S., \& Heath, T. (2016). Traditional Streetscape Adaptability: Urban gentrification and endurance of business. Environment-Behaviour Proceedings Journal, 1(4), 132. https://doi.org/10.21834/e-bpj.v1i4.378

Ujang, N. (2016). Defining Place Attachment in Asian Urban Places through Opportunities for Social Interactions. Environment-Behaviour Proceedings Journal, 1(1), 28. https://doi.org/10.21834/e-bpj.v1i1.191

Ujang, N., Moulay, A., \& Zakaria, J. (2018). Visitors' Attachment to Historic Tourism Places in Kuala Lumpur City Centre towards Sustainable Urban Regeneration. Environment-Behaviour Proceedings Journal, 3(9), 165. https://doi.org/10.21834/e-bpj.v3i9.1521

Vazquez, L. (2014). Creative Placemaking: Integrating Community, Cultural and Economic Development. SSRN Electronic Journal, (March). https://doi.org/10.2139/ssrn.2474862

Wyckoff, B. M. A. (2014). Definition of Placemaking: Four Different Types. Planning \& Zoning News, 1. Retrieved from www.miplace.org.

Zitcer, A. (2018). Making Up Creative Placemaking. Journal of Planning Education and Research, (January), 0739456X1877342. https://doi.org/10.1177/0739456x18773424 